\title{
Development and Validation of UV Spectrophotom- etric Method for Simultaneous Estimation of Omeprazole and Domperidone in Capsule Dosage forms
}

\author{
Javali B, Sravanthi B, Mohan Rao B, Gopi K, Vamsi K, Lakshmana Rao A and Prasanthi T* \\ Department of Pharmaceutical Analysis, V. V. Institute of Pharmaceutical Sciences, India
}

Submission: January 23, 2017; Published: February 20, 2017

*Corresponding author: Prasanthi T, Department of Pharmaceutical Analysis, V.V. Institute of Pharmaceutical Sciences, India;

E-mail: prasanthi8585@gmail.com

\begin{abstract}
A simple, precise, rapid and accurate UV Spectrophotometric method has been developed and validated for the simultaneous estimation of Omeprazole (OMP) and Domperidone (DOM) in combined pharmaceutical dosage forms. The method was developed by using methanol as a solvent. Omeprazole exhibits absorption maximum at $301 \mathrm{~nm}$ and Domperidone shows absorption maximum at $287.2 \mathrm{~nm}$ in methanol. The developed method was obeyed Beer Lambert's law in the concentration range of 2-12 $\mu \mathrm{g} / \mathrm{mL}$ for both OMP and DOM. The accuracy of method was confirmed by recovery studies from capsules at three different levels of standard additions. \%RSD values below 2 for intra-day and inter-day precision indicates that the proposed method is highly reproducible. The results of study demonstrated that the proposed method can be applied to formulation and for routine analysis.
\end{abstract}

Keywords: Omeprazole; Domperidone; Estimation; Spectrophotometry; Dosage form

Introduction

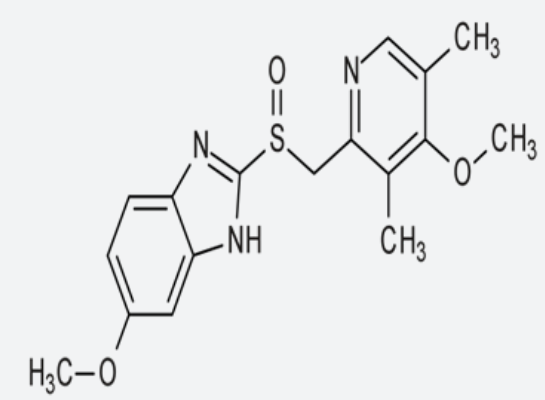

Figure 1: Molecular structure of Omeprazole.

Omeprazole (Figure 1) chemically (RS)-5-methoxy-2((4-methoxy-3,5-dimethylpyridin-2-yl) methylsulfinyl)-1Hbenzo[d]imidazole[1] is a proton pump inhibitor used is a benzimidazole derivative used in the treatment of dyspepsia, peptic ulcer disease, gastro esophageal reflux disease, laryngopharyngeal reflux and Zollinger-ellison syndrome [2]. In peptic ulcers, it suppresses gastric acid secretion by specific inhibition of the $\mathrm{H}+/ \mathrm{K}+$-ATPase in the gastric parietal cell. Domperidone (Figure 2) chemically 5-chloro-1-\{1-[3-(2-oxo-
2,3-dihydro-1H-1,3-benzodiazol-1-yl)propyl]piperidin-4-yl\}2,3-dihydro-1H-1,3-benzodiazol-2-one is a dopamine antagonist with antiemetic and gastrokinetic properties used to treat nausea and vomiting. Domperidone facilitates gastric emptying and decreases small bowel transit time by increasing esophageal and gastric peristalsis and by lowering esophageal sphincter pressure [3]. Few analytical methods of HPTLC [4], HPLC [5-7] and UV Spectrophotometry [8-10] have been reported for the simultaneous determination of Omeprazole and Domperidone in combined pharmaceutical dosage forms.

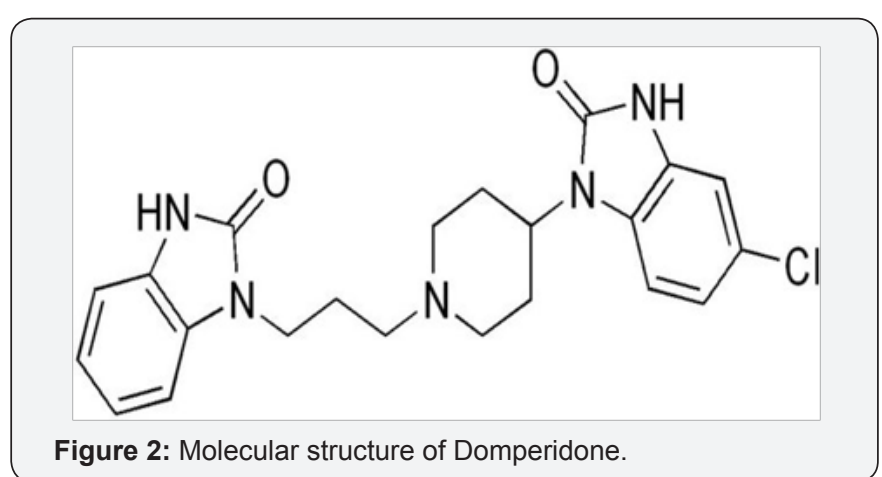




\section{Materials and Methods}

\section{Instrument}

Shimadzu UV1800 Double Beam UV-Visible Spectrophotometer was used for spectral studies.

\section{Chemicals and reagents}

Standard drug samples of Omeprazole (API) and Domperidone (API) were obtained from Yarrow Chem Products, Mumbai, India. The commercial formulation of Omeprazole and Domperidone capsules were procured from the local market.

\section{Preparation of standard stock solution}

The standard stock solutions of OMP and DOM were prepared separately by dissolving accurately weighed $100 \mathrm{mg}$ of drug in methanol and volume was made up to $100 \mathrm{~mL}$ with methanol to get concentration of $1 \mathrm{mg} / \mathrm{mL}$ From the stock solution prepare working standard solution of $100 \mu \mathrm{g} / \mathrm{mL}$ concentration in methanol for both drugs.

\section{Determination of wavelength of maximum absorbance $(\lambda$ max)}

The standard solutions of both OMP and DOM were further diluted to get concentration of $10 \mu \mathrm{g} / \mathrm{mL}$. These solutions were scanned in the wavelength region of 200-400 $\mathrm{nm}$ and the $\lambda$ max was observed at $301 \mathrm{~nm}$ and $287.2 \mathrm{~nm}$ for Omeprazole and Domperidone respectively. The wavelength spectra of OMP and DOM in methanol are shown in (Figure $3 \& 4$ ) respectively.
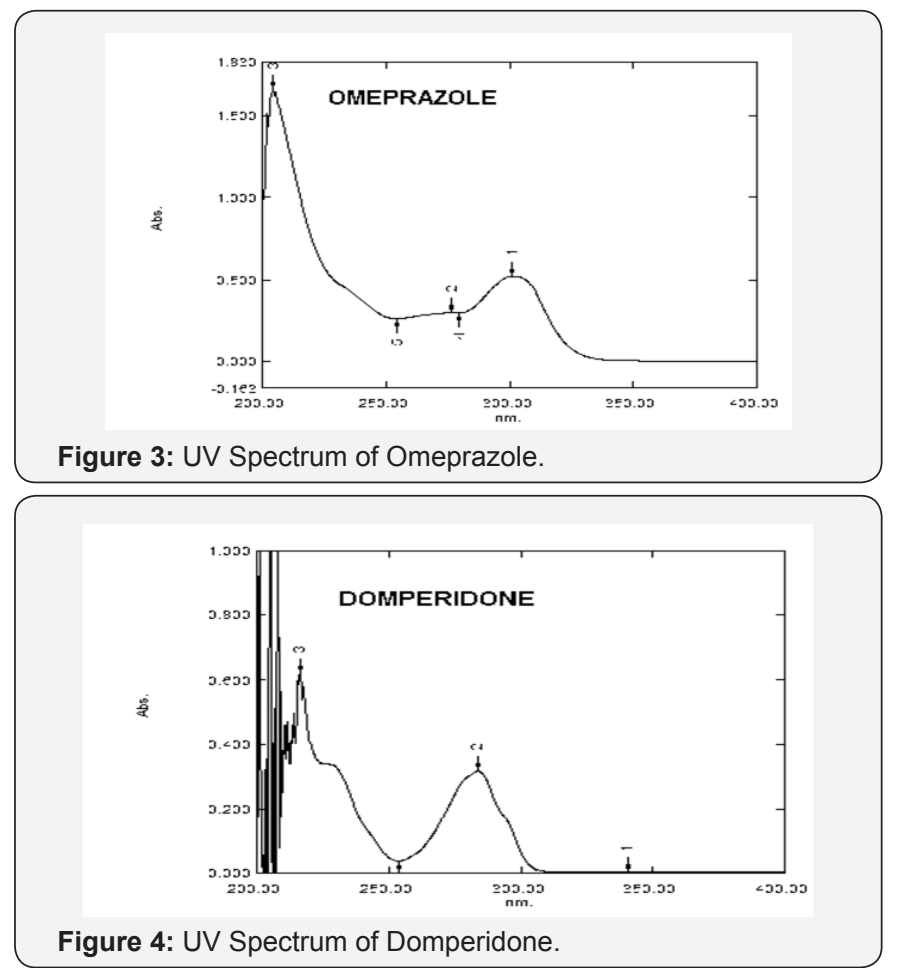

\section{Preparation of calibration curve}

Working standard solutions were prepared for the Omeprazole and Domperidone from the standard solution of
$100 \mu \mathrm{g} / \mathrm{mL}$. Different aliquots were taken from standard stock solution and diluted with methanol separately to prepare 2 $\mu \mathrm{g} / \mathrm{mL}, 4 \mu \mathrm{g} / \mathrm{mL}, 6 \mu \mathrm{g} / \mathrm{mL}, 8 \mu \mathrm{g} / \mathrm{mL} 10 \mu \mathrm{g} / \mathrm{mL}$ and $12 \mu \mathrm{g} / \mathrm{mL}$ solutions respectively. The absorbance values of Omeprazole and Domperidone were obtained at $301 \mathrm{~nm}$ and 287.2 $\mathrm{nm}$ respectively. The calibration curves were plotted with concentrations against absorbance and regression equation was calculated.

\section{Assay of capsule dosage form}

For the estimation of drugs in commercial formulations, twenty capsules containing $20 \mathrm{mg}$ of Omeprazole and $10 \mathrm{mg}$ of Domperidone were weighed and average weight was calculated. An accurately weighed portion of powder sample equivalent to one capsule weight was transferred into a $100 \mathrm{~mL}$ clean dry volumetric flask containing $70 \mathrm{~mL}$ of methanol. The contents of the flask were sonicated for $10 \mathrm{~min}$ and the volume was made up to the mark with a further quantity of the methanol to get a stock concentration of Omeprazole and Domperidone. Further pipette $5 \mathrm{~mL}$ of the above stock solution into a $10 \mathrm{~mL}$ volumetric flask and the volume was made up to the mark with the methanol.

\section{Results}
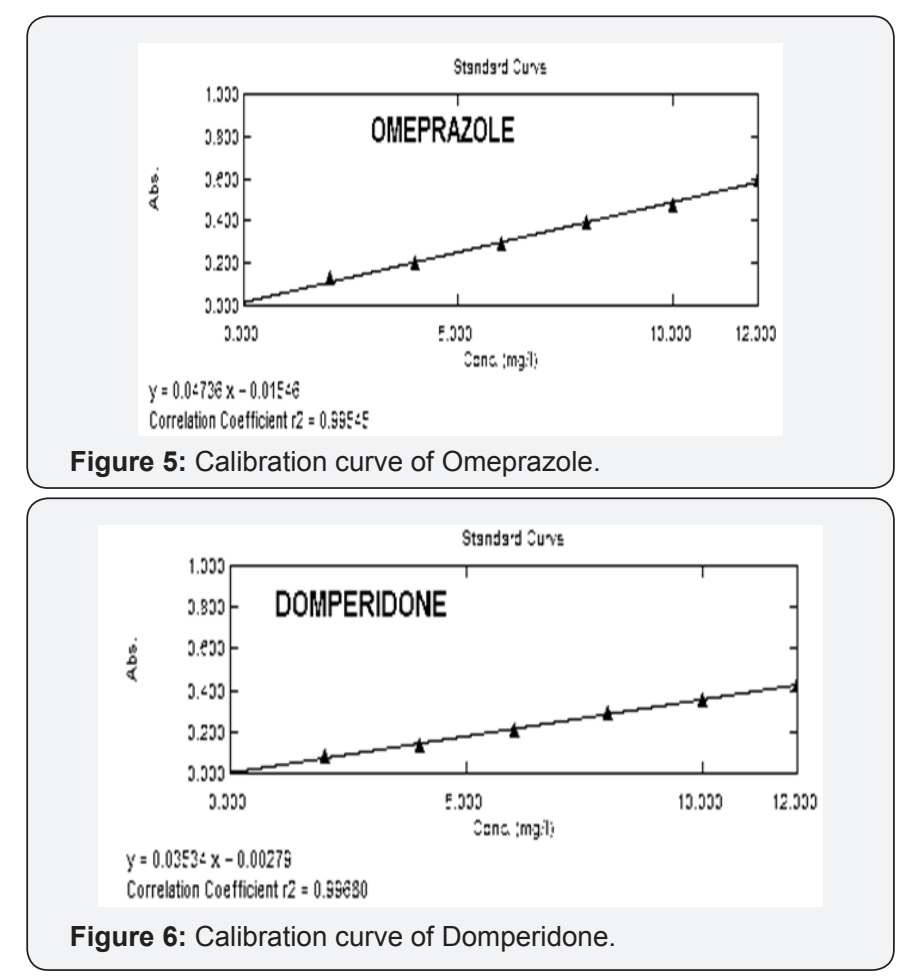

The present study was carried out to develop a simple, sensitive, precise and accurate UV spectrophotometric method for the simultaneous estimation of Omeprazole and Domperidone in pharmaceutical dosage forms. The wavelength spectrum of OMP and DOM exhibits at $301 \mathrm{~nm}$ and $287.2 \mathrm{~nm}$ respectively. Beer Lambert's law was obeyed in the concentration range of 2-12 $\mu \mathrm{g} / \mathrm{mL}$ for both OMP (Figure 5) and DOM (Figure 6). The regression equations for Omeprazole and Domperidone were 


\section{Global Journal of Pharmacy \& Pharmaceutical Sciences}

found to be $y=0.04736 x+0.01546$ and $y=0.03534 X+0.00279$ (Table 1) respectively with a correlation coefficient (r2) of 0.99545 for OMP and 0.99680 for DOM. Precision of the method was studied by repeated measurements of drug solution and results showed lower \%RSD values. The \%RSD for intra-day precision and inter-day precision for OMP were found to be $0.25 \%$ and $0.35 \%$ respectively. The $\%$ RSD for intra-day precision and inter-day precision (Table $2 \& 3$ ) for DOM were found to be 0.28 and 0.37 respectively. The percent recoveries for OMP and DOM were found to be $100.05 \%$ (Table 4) and $100.17 \%$ (Table 5) respectively. The limit of detection (LOD) and limit of quantification (LOQ) for Omeprazole were found to be $0.15 \mu \mathrm{g} /$ $\mathrm{mL}$ and $0.47 \mu \mathrm{g} / \mathrm{mL}$ respectively. The limit of detection (LOD) and limit of quantification (LOQ) for Domperidone were found to be $0.80 \mu \mathrm{g} / \mathrm{mL}$ and $2.45 \mu \mathrm{g} / \mathrm{mL}$ respectively (Table 6). The percentage purity for the assay of OMP and DOM were found to be $99.84 \%$ and $99.15 \%$ respectively (Table 7 ).

Table 1: Linearity results of Omeprazole and Domperidone.

\begin{tabular}{|c|c|c|c|}
\hline S. No. & $\begin{array}{c}\text { Concentration } \\
(\mu \mathrm{g} / \mathbf{m L})\end{array}$ & $\begin{array}{c}\text { Omeprazole } \\
\text { Absorbance }\end{array}$ & $\begin{array}{c}\text { Domperidone } \\
\text { Absorbance }\end{array}$ \\
\hline 1 & 0 & 0 & 0 \\
\hline 2 & 2 & 0.136 & 0.088 \\
\hline 3 & 4 & 0.204 & 0.133 \\
\hline 4 & 6 & 0.294 & 0.210 \\
\hline 5 & 8 & 0.393 & 0.351 \\
\hline 6 & 10 & 0.478 & 0.432 \\
\hline Slope & 0.01546 & 0.03543 & 0.504 \\
\hline Intercept & 0.004736 & 0.00279 & \\
\hline $\begin{array}{c}\text { Regression } \\
\text { Equation(y) }\end{array}$ & $0.04736 \mathrm{x}+$ & $0.03534 \mathrm{X}+$ & \\
\hline $\begin{array}{c}\text { Correlation } \\
\text { Coefficient(r2) }\end{array}$ & 0.01546 & 0.00279 & \\
\hline
\end{tabular}

Table 2: Intra-day precision results of Omeprazole and Domperidone.

\begin{tabular}{|c|c|c|c|}
\hline S. No. & Time (Hours) & $\begin{array}{c}\text { OMP } \\
\text { Absorbance }\end{array}$ & $\begin{array}{c}\text { DOM } \\
\text { Absorbance }\end{array}$ \\
\hline 1 & 0 & 0.478 & 0.432 \\
\hline 2 & 1 & 0.476 & 0.430 \\
\hline 3 & 2 & p0.479 & 0.429 \\
\hline 4 & 3 & 0.477 & 0.433 \\
\hline 5 & 4 & 0.476 & 0.432 \\
\hline 6 & 5 & 0.478 & 0.430 \\
\hline \multicolumn{2}{|c|}{ Mean } & 0.477 & 0.431 \\
\hline \multicolumn{2}{|c|}{ SD } & 0.001211 & 0.001549 \\
\hline \multicolumn{2}{|c|}{$\%$ RSD } & 0.25 & 0.35 \\
\hline
\end{tabular}

Table 3: Inter-day precision results of Omeprazole and Domperidone.

\begin{tabular}{|c|c|c|c|}
\hline S. No. & Time (Days) & $\begin{array}{c}\text { OMP } \\
\text { Absorbance }\end{array}$ & $\begin{array}{c}\text { DOM } \\
\text { Absorbance }\end{array}$ \\
\hline 1 & 1 & 0.478 & 0.432 \\
\hline 2 & 2 & 0.479 & 0.431 \\
\hline 3 & 3 & 0.476 & 0.430 \\
\hline 4 & 4 & 0.480 & 0.434 \\
\hline 5 & 5 & 0.479 & 0.430 \\
\hline 6 & 6 & 0.478 & 0.430 \\
\hline \multicolumn{2}{|c|}{ Mean } & 0.478 & 0.431 \\
\hline SD & 0.001362 & 0.0016 \\
\hline \multicolumn{2}{|c|}{ \%RSD } & 0.28 & 0.37 \\
\hline
\end{tabular}

Table 4: Recovery studies for Omeprazole.

\begin{tabular}{|c|c|c|c|c|c|}
\hline Level & $\begin{array}{l}\text { Standard } \\
\text { conc. } \\
(\mu \mathrm{g} / \mathrm{mL})\end{array}$ & $\begin{array}{c}\text { Conc. } \\
\text { added } \\
(\mu \mathrm{g} / \mathrm{mL})\end{array}$ & 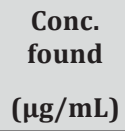 & $\begin{array}{c}\% \\
\text { Recovery }\end{array}$ & $\begin{array}{l}\text { \% Mean } \\
\text { Recovery }\end{array}$ \\
\hline $80 \%$ & 10 & 8 & 8.02 & 100.25 & \multirow{3}{*}{100.05} \\
\hline $100 \%$ & 10 & 10 & 9.87 & 99.70 & \\
\hline $120 \%$ & 10 & 12 & 11.89 & 99.08 & \\
\hline
\end{tabular}

Table 5: Recovery studies for Domperidone.

\begin{tabular}{|c|c|c|c|c|c|}
\hline Level & $\begin{array}{c}\text { Standard } \\
\text { conc. } \\
(\mu \mathrm{g} / \mathrm{mL})\end{array}$ & $\begin{array}{c}\text { Conc. } \\
\text { added } \\
(\mu \mathrm{g} / \mathrm{mL})\end{array}$ & $\begin{array}{c}\text { Conc. } \\
\text { found } \\
(\mu \mathrm{g} / \mathrm{mL})\end{array}$ & $\begin{array}{c}\% \\
\text { Recovery }\end{array}$ & $\begin{array}{l}\text { \% Mean } \\
\text { Recovery }\end{array}$ \\
\hline $80 \%$ & 10 & 8 & 7.95 & 99.37 & \multirow{3}{*}{100.17} \\
\hline $100 \%$ & 10 & 10 & 10.05 & 100.50 & \\
\hline $120 \%$ & 10 & 12 & 12.07 & 100.66 & \\
\hline
\end{tabular}

Table 6: LOD and LOQ of Omeprazole and Domperidone.I

\begin{tabular}{|c|c|c|}
\hline Parameter & $\begin{array}{c}\text { Omeprazole } \\
\text { Measured value } \\
(\mu \mathrm{g} / \mathrm{mL})\end{array}$ & $\begin{array}{c}\text { Domperidone } \\
\text { Measured value } \\
(\boldsymbol{\mu g} / \mathrm{mL})\end{array}$ \\
\hline Limit of detection & 0.15 & 0.80 \\
\hline $\begin{array}{c}\text { Limit of } \\
\text { quantification }\end{array}$ & 0.47 & 2.45 \\
\hline
\end{tabular}

Table 7: Assay results of Omeprazole and Domperidone formulations.

\begin{tabular}{|c|c|c|c|c|}
\hline \multicolumn{2}{|c|}{ Formulation } & $\begin{array}{c}\text { Label } \\
\text { claim }\end{array}$ & $\begin{array}{c}\text { Amount } \\
\text { found }\end{array}$ & \%Assay \\
\hline \multirow{2}{*}{ OMEE-D } & Omeprazole & $20 \mathrm{mg}$ & $19.98 \mathrm{mg}$ & $99.84 \%$ \\
\cline { 2 - 5 } & Domperidone & $10 \mathrm{mg}$ & $9.82 \mathrm{mg}$ & $99.15 \%$ \\
\hline
\end{tabular}

\section{Conclusion}

The UV spectrophotometric method for the simultaneous determination of Omeprazole and Domperidone in marketed formulations was developed and validated as per ICH guidelines. The satisfying recoveries, low correlation coefficient and assay results confirmed the suitability of proposed method for the routine quality control analysis for simultaneous determination of OMP and DOM in pharmaceutical formulations. The \% RSD values for the proposed method reveals high degree of precision of method.The assay and validation results are satisfactory and 
therefore the developed method can used for routine analysis of formulations without interference from excipients.

\section{References}

1. Indian Pharmacopoeia (2014) The Indian Pharmacopoeia Commission, Ghaziabad, India. Voilume-II: 2372(OMP) \& 1612(DOM).

2. U.S. Pharmacopoeia National Formulary (2014) The Unites States Pharmacopoeial Convention, Rockville, MD, USA Volume III: 4063 (OMP).

3. Gupta KK, Sase D, Faulds (2012) Drug review on Domperidone. Asian Journal of pharmaceutical sciences 1(11): 366-369.

4. Bhavesh Patel, Bhanubhai Suhagia, Jignesh Patel, Madhabhai Patel (2007) Simultaneous determination of Omeprazole and Domperidone in capsules by RP-HPLC and densitometric HPTLC. Journal of Liquid Chromatography \& Related Technologies 30(12): 1749-1762

5. Subramanian L, Anil Kumar V (2012) Simultaneous HPLC estimation of Omeprazole and Domperidone from tablets. Indian Journal of Pharmaceutical Sciences 69(5): 674-676.
6. Rami Reddy YV, Krishnaiah V (2012) Development and validation of HPLC method for simultaneous determination of Omeprazole and Domperidone. Scholars Research Library Der Pharma Chemica 4(1): 455-459.

7. Fabio SM, Shradha Chauhan (2008) Simultaneous estimation and validation of Omeprazole and Domperidone by HPLC method. Indian Journal Pharmaceutical Sciences 70(1): 128-131.

8. Sudhakar Rao GV, Sujana K, Pedababu T (2014) Development and validation of UV spectrophotometric method for the estimation of Omeprazole in bulk and pharmaceutical formulations. International Journal of Pharmacy 2(1): 247-251.

9. Subrahmanyam S, Prasad RY, Rajasekhar KK, Shankarananth V, Yaminikrishna, et al. (2009) Spectrophotometric method for the estimation of Domperidone in bulk and pharmaceutical formulations. Journal of Pharmacy research 2(10): 15-18.

10. Balakrishna MV, Surekha B, Anita SK (2011) Development of UV Spectrophotometric method for simultaneous estimation of Omeprazole and Domeperidone in capsule dosage form. Asian Journal of Research in Chemistry 4(7): 1119-1124.

Your next submission with Juniper Publishers will reach you the below assets

- Quality Editorial service

- Swift Peer Review

- Reprints availability

- E-prints Service

- Manuscript Podcast for convenient understanding

- Global attainment for your research

- Manuscript accessibility in different formats ( Pdf, E-pub, Full Text, Audio)

- Unceasing customer service

Track the below URL for one-step submission https://juniperpublishers.com/online-submission.php 